\title{
Seroprevalence of Porcine Cysticercosis in South-Eastern Côte d'Ivoire
}

\author{
Kouassi Eugene Koffi 1,2, Man-Koumba Soumahoro ', Kouadio Borel N'Dri ${ }^{1}$, Mireille Nowakowski ${ }^{3}$, Cataud \\ Marius ${ }^{1}$, O Marcel Boka ${ }^{4}$, Jihen Melki ${ }^{1}$, André Offianan Touré ${ }^{1}$, Joseph Djaman ${ }^{1}$, Jacques Bellalou ${ }^{3}$, Eliezer \\ $\mathrm{N}^{\prime}$ Goran ${ }^{2}$, and Ronan Jambou 1,5*
}

\author{
Institut Pasteur de Côte d'Ivoire, Abidjan, Côte d'Ivoire ; eugenekoffi2@yahoo.fr (KEK) ; mksouma- \\ horo@pasteur.ci (MKS) ; ndriborel@gmail.com (KBN); jihenmelki@gmail.com (JM) ; andretoure@pasteur.ci \\ (OAT) ; djamanj@yahoo.fr(JD) ; cataud.marius@yahoo.fr (CMG) ; \\ 2 Laboratoire de zoologie et Biologie Animale Félix Houphouët Boigny, Abidjan, Côte d'Ivoire; eliezern- \\ goran@yahoo.fr (KEN); \\ 3 Institut Pasteur, Paris, France ; jacques.bellalou@pasteur.fr (JB); \\ 4 Centre d'Entomologie Médicale et Vétérinaire, Université Alassane Ouattara, Bouaké, Côte d'Ivoire ; mar- \\ celboka2@yahoo (OMB) ; \\ 5 Institut Pasteur, Paris 75015, France, rjambou@pasteur.fr (RJ);
}

\begin{abstract}
Background : porcine cysticercosis is an endemic parasitic zoonosis in many developing countries. The objective was to estimate the seroprevalence of porcine cysticercosis in traditional pig farms in the departments of Dabou, Aboisso and Agboville where blood samples were taken from pigs and analyzed by ELISA (IgG) and western blot. Data on farming practices and pig characteristics were collected. Categorical variables were compared with the Chi2 test and continuous variables with the Student test. Multivariate logistic regression models were constructed to identify risk factors. Results: A total of 668 pigs were sampled from 116 farms. The seroprevalence of cysticercosis was estimated at $13.2 \%$. Overweight [ORa $=2.6 ; 95 \% \mathrm{CI}(1.3-4.9)]$ and fat pigs $[\mathrm{ORa}=2.3 ; 95 \% \mathrm{CI}(1.0-4.8)]$ were twice as likely to be seropositive for cysticercosis. This risk was increased in farms using well water for drinking [aOR=2.5; 95\% $\mathrm{CI}(1.0-6.3)]$ as well as those reporting veterinary care of the animals $(\mathrm{ORa}=2.9 ; 95 \% \mathrm{CI}(1.2-7.3))$. Conclusions: This study demonstrated the circulation of T. solium in pig farms in southern Côte d'Ivoire.
\end{abstract}

Keywords: Taenia solium; seroprevalence; porcine Cysticercosis ; Côte d'Ivoire.

\section{Introduction}

Porcine cysticercosis is a larval cestodosis caused by Taenia solium. It is linked to the ingestion by pigs of the eggs of the parasite present in food or water contaminated by human faeces. Man is the definitive host in the biological cycle, and accidentally, the intermediate host such as pigs.

With the exception of regions where the breeding and the consumption of pigs is a religious taboo, porcine cysticercosis probably affects all countries south of the Sahara where the conditions for the persistence this zoonosis are generally met: poor hygiene and sanitation conditions, rural areas with permanent or seasonal pig roaming and lack of inspection of pig meat [1]. This disease is an economic and public health concern in almost all of sub-Saharan Africa, except in Muslim areas [2]. However, in pigs, the disease is most often asymptomatic, whereas in humans, cysticercosis induces polymorphic signs dominated by epilepsy [3].

In Côte d'Ivoire, very few data concerning porcine cysticercosis are available. When available, they are mostly pretty old. Indeed, in 1978, authors estimated the national prevalence of swine cysticercosis in Côte d'Ivoire at $2.5 \%$ with the most prevalent area 
in Bouaké (5.7\%) and Korhogo (3.9\%) districts [4]. In 1991, Danho et al. reported a national prevalence of 3.6\% [5]. Between 2013 and 2014, the Veterinary Services reported 151 cases of cysticercosis lesions observed in pig carcasses collected at the Société Ivoirienne d'abattage et de Charcuterie (SIVAC) [6]. This suggests an active circulation of Taenia solium in pigs in Côte d'Ivoire.

Pork meat is widely consumed in Côte d'Ivoire, especially from pigs, raised in a traditional way in villages. In this setting, most of the pigs are slathered in absence of veterinary control. It was thus urgent to reevaluate the circulation of the parasite in order to contribute to food safety. The objective of this study was to estimate the seroprevalence of swine cysticercosis in rural areas of southern Côte d'Ivoire and to identify its determinants. These areas provide most of the pork meat sells in Abidjan the economic capital of the country, accounting nowadays for six million inhabitants.

\section{Materials and Methods}

Type and setting of the study

A cross-sectional survey was conducted in three rural areas of the southern region of Côte d'Ivoire, i.e. the districts of Dabou, Agboville and Aboisso. These localities were chosen as study sites according to the importance of their traditional pig farming and their role in supplying the city of Abidjan (the economic capital) with pork. The department of Dabou, is located to the East of Abidjan, extending between $5^{\circ} 19^{\prime}$ North latitude and $4^{\circ} 23^{\prime}$ West longitude over an area of about $2260 \mathrm{~km} 2$. The vegetation is characterized by a dense forest. The climate is sub-equatorial with an annual rainfall of $2000 \mathrm{~mm}$. The district of Agboville, it is located between $5^{\circ} 55^{\prime} 41^{\prime \prime}$ North latitude and $4^{\circ} 13^{\prime} 01^{\prime \prime}$ West longitude, with a surface area of $12000 \mathrm{~km} 2$ and a vegetation characterized by a dense semi-deciduous humid forest. The average annual rainfall is about $1400 \mathrm{~mm}$ with a humid tropical climate [7]. Aboisso is located in the south-east part of Côte d'Ivoire between longitude $2^{\circ} 40$ and $3^{\circ} 40$ West and latitude $5^{\circ}$ and $6^{\circ} 20$ North, $116 \mathrm{~km}$ from Abidjan and $60 \mathrm{~km}$ from the Ghana border. The department of Aboisso covers an area of $4662.17 \mathrm{~km}^{2}$ with a very uneven relief, a hot and rainy climate of equatorial type and a vegetation characterized by dense forests.

The population of study

The population of study consisted of pigs selected from villages with herds of more than 10 pigs. It was planned to include 600 pigs to demonstrate an expected seroprevalence of $50 \%$ with a precision of $7 \%$ at a risk of error $\alpha$ of $5 \%$ and a power of $90 \%$. The number of pigs to be sampled per department was determined by the quota method using pig census data obtained during preliminary investigations conducted by the $\mathrm{Na}$ tional Agency for Support to Rural Development (ANADER). Thus, it was planned to include at least 243, 197 and 160 village pigs in Agboville, Dabou and Aboisso respectively, for a total of 600 pigs. With the consent of the farmer to participate in the study, pigs selected were at least 3 months.

Data collection

The data were collected using a structured questionnaire proposed to each breeder. It was related to the socio-demographic characteristics of the household (age, sex, seniority, level of education) and to the characteristics of the farm (system and type of breeding, feeding, water, veterinary care, feeding). In addition, direct observations were made on the environment of the barn (presence of latrine, level of hygiene). A $4 \mathrm{ml}$ blood sample was taken from each animal included in the study using a dry tube. Information regarding the characteristics of each animal collected (age, weight, breed, type, health status and general condition of the animal) was also collected.

Biological tests

Detection of antibodies against cysticercosis was performed using the glycosylated fraction of the cyst as antigen [8]. Sera were first analyzed by ELISA (IgG) and positive sera were subjected to secondary analysis by western blot (IgG). Negative controls used to define the threshold of positivity were piglet sera from industrial herds. For this study, 
positive pig was defined as serology positive both with ELISA and Western blot. The presence of at least two bands among P6-8, P12, P23-26, P39, P45 was used to define positive western blot [9]. The P50-55 band was not considered in this study as it is thought to be cross-reactive with Thydatigena, a porcine taenia [10].

statistical analysis

Quantitative variables were described by their mean and standard deviation and qualitative variables by proportions. Dependent variables were, the presence of cysticercosis-positive pigs in the farms or cysticercosis positive serology of the pig. The determinants for the presence of cysticercosis-positive pigs in the farms and for seropositivity of the pigs were analyzed using logistic regression models. To do this, variables were first selected for the models by univariate analyses. Categorical variables were compared with the $\mathrm{Chi}^{2}$ test or Fisher's exact test, if applicable, and quantitative variables with the Student's or Wilcoxon's test. Backward logistic regression models were constructed with variables associated with the dependent variables with a significance level of $\mathrm{p}<20 \%$ during univariate analyses. The final models retained only the variables associated with the dependent variables at the 5\% level in a two-sided formulation.

Data were entered from Epidata 3.1 software and Stata ${ }^{\mathrm{TM}}$ software, version 11, used for the analyses.

Ethical considerations

All the breeders were informed about the objectives and the procedures of the study. A consent was obtained for each breeder before inclusion. The study was approved by the National Ethics Committee of Côte d'Ivoire under the number of 123/MSHP/CNER-dk on 24 November 2016.

\section{Results}

\subsection{Description of the study population}

\subsubsection{Characteristics of the pig farms}

Out of the 124 farmers contacted between February 2017 and February 2018, 116 $(93.5 \%)$ agreed to participate in the study. Indeed, 8 farmers refused to participate: 1 in Dabou; 2 in Aboisso and 5 in Agboville. The study revealed a predominance of males $(82.8 \%)$ among the farmers, with a M/F sex ratio of 4.8 . More than half of them (56\%) were over 45 years old; $36.2 \%$ had not attended school and $85.3 \%$ had been farming for more than one year. Slightly more than half of the selected farms were located in the department of Agboville (51\%). See Table 1.

In the department of Dabou, 33 farms were visited in 8 villages. The majority of the farms (33.3\%) were located in the village of Cosrou. In Agboville, 59 pig farms were visited in 13 villages, with the majority in the village of Boka Oh'O. The number of farms varied from 1 to 12 in the villages. In the Department of Aboisso, farms were selected in 10 villages with a maximum of farms visited in the village of Bodjénou. The number of farms visited varied from 1 to 7 . Cysticercosis-positive pigs was observed in $41.4 \%$ of the farms visited (Figure 1).

Table 1. Socio-demographic characteristics of livestock farmers visited in the departments of Dabou, Aboisso and Agboville.

\begin{tabular}{llc}
\hline Variables & Items & Total N (\%) \\
\hline \multirow{2}{*}{ Sex } & Male & $96(82.8)$ \\
& Female & $20(17.2)$ \\
\hline \multirow{2}{*}{ Age group } & From 18 to 45 years & $51(44.0)$ \\
& More than 45 years & $65(56.0)$ \\
\hline
\end{tabular}




\begin{tabular}{llc}
\hline & None & $42(36.2)$ \\
Education level & Primary school & $39(33.6)$ \\
& Secondary school & $33(28.5)$ \\
& Higher Education & $02(01.7)$ \\
\hline & Less than 6 months & $05(4.3)$
\end{tabular}

Duration in the farmBetween 6 and 12 months $12(10.3)$

\begin{tabular}{lll} 
& More than 12 months & $99(85.4)$ \\
\hline \multirow{3}{*}{ Farm location } & Aboisso & $24(20.7)$ \\
& Agboville & $59(50.9)$ \\
& Dabou & $28(28.4)$ \\
\hline
\end{tabular}

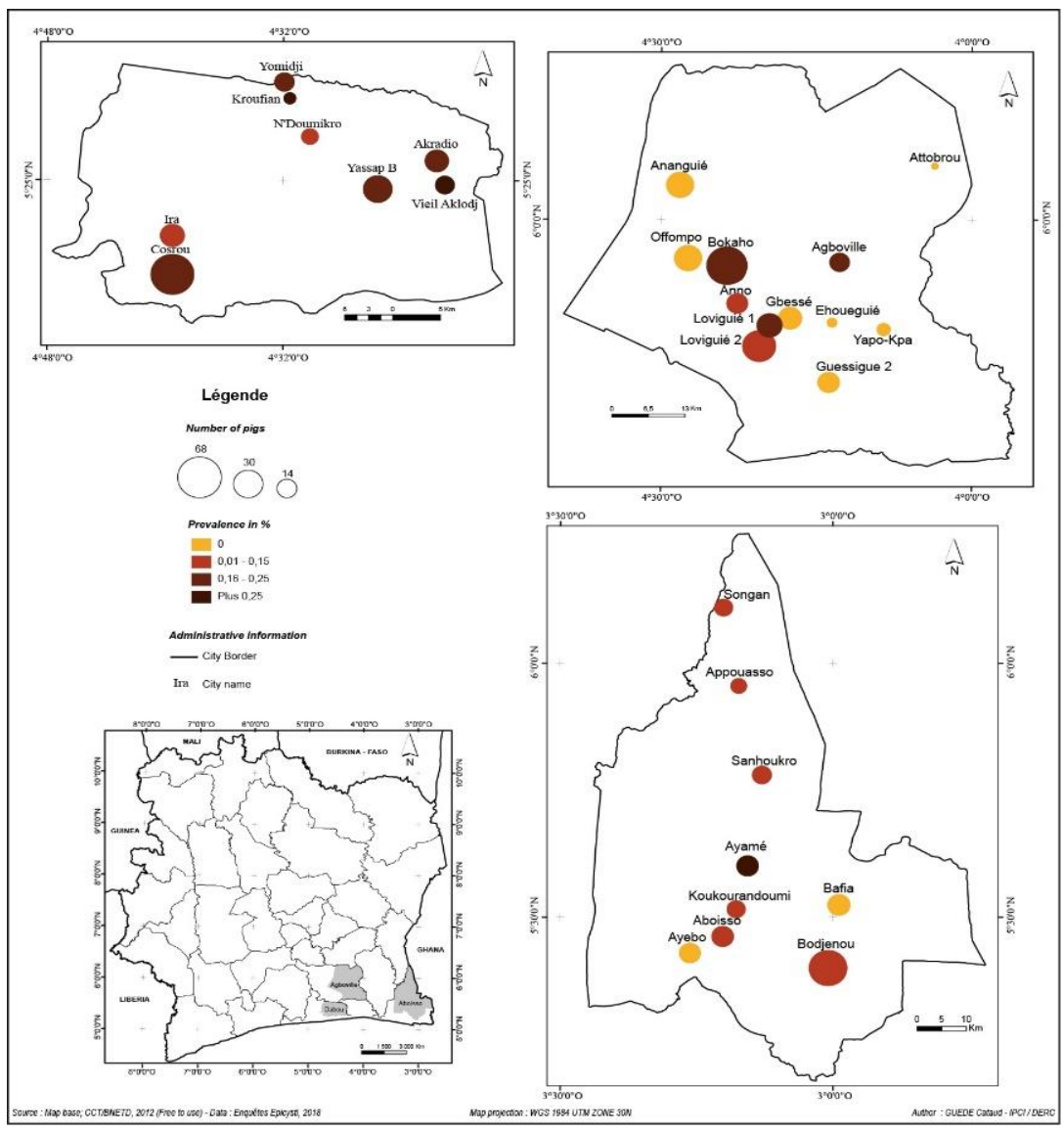

Figure 1. Geographical distribution of farms included in the study.

Among the 116 farms visited, 84.5\% practiced traditional type breeding with permanent straying in $62 \%$ of cases. The presence of a latrine and the notion of washing of the pigsty were reported respectively in $25.2 \%$ and $6.1 \%$ of the farms. Only $8.7 \%$ of farmers had declared disinfecting their farms. In addition, the majority of pigsties were located within 100 meters of open defecation sites (87\%), household waste dumps (88.7\%) and pigs watering places (backwater, stagnant water, $88.7 \%$ ). The presence of piping was observed only in $4.4 \%$ of farms (table 2 ).

Most of the farmers (96.5\%) declared not using commercial foods to feed animals. Those who reported using commercial foods (3.5\%) also declared using only locallymade products. $12.2 \%$ of breeders reported feeding their animals with homemade compound foods while $86.1 \%$ of them reported feeding their animals with household wastes. 
About animals watering, breeders mentioned several sources, i.e. borehole water $(9.9 \%)$, wells $(32.4 \%)$, running water $(21.6 \%)$, watercourses $(47.8 \%) \%)$ or runoff water (37.1\%).

Among the 40 farmers who asserted to provide veterinary follow-up to their herds, $57.5 \%$ reported using anti-parasite with mainly Ivermectin (78.3\%) or Albendazole (13.04\%). $88.9 \%$ of them declared having dewormed animals less than 3 months ago. In addition, breeders also asserted to use antibiotics (45\%), anti-inflammatory drugs (7.5\%), vitamins $(37.5 \%)$, and $30 \%$ of them declared practicing disinfection of the pens. However, among the 116 farmers questioned, 97.3\% used not to know the slaughter age of their pigs. (table 2).

The average size of the farms visited was $22 \pm 41$ pigs ranging from 1 to 300 pigs, (median number and interquartile range: 11 (5.5 - 20)). The herds were composed on average of $6 \pm 7$ sows $(\min =0$ and $\max =50), 2 \pm 3$ boars $(\min =0$ and $\max =20)$ and $7 \pm$ 9 piglets $(\min =0$ and $\max =41)$.

Table 2. Characteristics of farms according to the presence of seropositive pigs in the farm.

\begin{tabular}{|c|c|c|c|c|}
\hline \multirow{2}{*}{ Parameters } & \multirow{2}{*}{ Items } & \multicolumn{3}{|c|}{ Presence of seropositive pigs } \\
\hline & & No & Yes & \\
\hline \multirow{2}{*}{ Type of breeding } & Improved & $7(10.3)$ & $11(22.9)$ & $0.06^{2}$ \\
\hline & Traditional & $61(89.7)$ & $37(77.1)$ & \\
\hline \multirow{3}{*}{ Breeding mode } & Permanent wandering & $47(69.1)$ & $25(52.1)$ & \\
\hline & Partial wandering & 13(19.1) & $9(18.7)$ & $0.055^{2}$ \\
\hline & Enclosure breeding & $8(11.8)$ & $14(29.2)$ & \\
\hline \multirow[t]{2}{*}{ Presence of latrine } & No & $46(67.7)$ & $40(85.1)$ & $0.034^{2}$ \\
\hline & Yes & $22(32.3)$ & $7(14.9)$ & \\
\hline \multirow[t]{2}{*}{ Pigsty washing } & No & $65(97.0)$ & $42(89.4)$ & $0.12^{1 ; 2}$ \\
\hline & Yes & $02(3.0)$ & $05(10.6)$ & \\
\hline \multirow[t]{2}{*}{ Pigsty desinfection } & No & $62(91.2)$ & $43(91.5)$ & $1.000^{1}$ \\
\hline & Yes & $06(08.8)$ & $04(08.5)$ & \\
\hline \multirow{3}{*}{ Distance between landfill and farm } & $<10 \mathrm{~m}$ & $58(85.3)$ & $33(70.2)$ & $0.085^{1 ; 2}$ \\
\hline & Between 10 and 100 m & 06(08.8) & $05(10.6)$ & \\
\hline & More than $100 \mathrm{~m}$ & $04(5.9)$ & 09(19.2) & \\
\hline \multirow{2}{*}{ Presence of drains } & No & $66(97.1)$ & $44(93.6)$ & $0.398^{1}$ \\
\hline & Yes & $02(02.9)$ & $03(06.4)$ & \\
\hline \multirow{2}{*}{ Consumption of commercial food } & No & $65(97.0)$ & $46(95.8)$ & $1.000^{1}$ \\
\hline & Yes & $02(03.0)$ & $02(04.2)$ & \\
\hline \multirow{2}{*}{ Consumption of farm-produced food } & No & $63(94.0)$ & $38(79.2)$ & $0.016^{2}$ \\
\hline & Yes & $04(06.0)$ & $10(20.8)$ & \\
\hline \multirow{2}{*}{ Consumption of food from household waste } & No & 08(11.9) & $08(16.8)$ & 0.470 \\
\hline & Yes & $59(88.1)$ & $40(83.3)$ & \\
\hline \multirow{2}{*}{ Watering with borehole water } & No & $58(90.6)$ & $42(89.4)$ & $1.000^{1}$ \\
\hline & Yes & $06(9.4)$ & $05(10.6)$ & \\
\hline \multirow[b]{2}{*}{ Drinking with well water } & No & $49(76.5)$ & $26(55.3)$ & $0.018^{2}$ \\
\hline & Yes & $15(23.4)$ & $21(44.7)$ & \\
\hline \multirow{2}{*}{ Drinking with running water } & No & $50(78.1)$ & $37(78.7)$ & 0.940 \\
\hline & Yes & $14(21.9)$ & $10(21.3)$ & \\
\hline Watering with streams & No & $31(47.0)$ & $28(59.6)$ & $0.186^{2}$ \\
\hline
\end{tabular}




\begin{tabular}{|c|c|c|c|c|}
\hline & Yes & $35(53.0)$ & 19(40.4) & \\
\hline \multirow{2}{*}{ Watering with runoff water } & No & $38(55.9)$ & $35(72.9)$ & $0.061^{2}$ \\
\hline & Yes & $30(44.1)$ & $13(27.1)$ & \\
\hline \multirow{2}{*}{ Veterinary care } & No & $52(76.5)$ & $24(50.0)$ & $0.003^{2}$ \\
\hline & Yes & $16(23.5)$ & $24(50.0)$ & \\
\hline Average number of pigs selected per farm ( $m \pm E T)$ & & $4.6 \pm 0.3$ & $7.4 \pm 0.7$ & $0.0001^{2}$ \\
\hline
\end{tabular}

${ }^{1}$ Fisher's exact test ; ${ }^{2}$ Variables selected for the multivariate model

\subsubsection{Characteristics of the pigs selected}

The total number of pigs sampled was 668 with 208 (31.1\%) in Dabou, $182(27.3 \%)$ in Aboisso and 278 (41.6\%) in Agboville. The majority of pigs sampled were of local breed (51.8\%) and most often they were female (72.3\%). Most of these animals were over 12 months old (37.3\%) and generally weighed between 10 and $30 \mathrm{~kg}(32.8 \%)$. Most of the herds were composed of reproductive animals $(61.5 \%)$ and half of them were overweight. On examination, $58.7 \%$ of the pigs showed symptoms of various diseases and the presence of parasites was observed in 232 of 346 (67\%) pigs.

An Elisa serology was carried out for 639 pigs among which 253 (39.6\%) were positive. Western blot technique was used for 243 Elisa positive sera in order to confirm the result. Thus, $83(13.2 \%)$ pigs were found to be seropositive for cysticercosis (table 3).

Table 3. Characteristics of the pigs selected from the farms visited

\begin{tabular}{|c|c|c|c|}
\hline Variables & Items & $\mathbf{N}$ & $(\%)$ \\
\hline \multirow{3}{*}{ Departement } & Aboisso & 183 & 27.3 \\
\hline & Agboville & 278 & 41.6 \\
\hline & Dabou & 208 & 31.1 \\
\hline \multirow{3}{*}{ Race } & Local & 346 & 51.8 \\
\hline & Metis & 304 & 45.5 \\
\hline & improved & 18 & 2.7 \\
\hline \multirow{2}{*}{ Sex } & Male & 185 & 27.7 \\
\hline & Female & 483 & 72.3 \\
\hline \multirow{3}{*}{ Animal age group } & $<6$ months & 179 & 26.8 \\
\hline & Between 6 and 12 months & 240 & 35.9 \\
\hline & $>12$ months & 249 & 37.3 \\
\hline \multirow{4}{*}{ Animal weight } & $<10 \mathrm{Kg}$ & 200 & 29.9 \\
\hline & Between 10 et $30 \mathrm{Kg}$ & 219 & 32.8 \\
\hline & Between 30 and $70 \mathrm{Kg}$ & 183 & 27.4 \\
\hline & $>70 \mathrm{Kg}$ & 66 & 09.9 \\
\hline \multirow{4}{*}{ Animal type } & Pig Breeder & 411 & 61.5 \\
\hline & Piglet & 209 & 31.3 \\
\hline & Pig butcher & 38 & 05.7 \\
\hline & reformed pig & 10 & 01.5 \\
\hline \multirow{3}{*}{$\begin{array}{l}\text { General condition of the } \\
\text { animal }\end{array}$} & Lean & 201 & 30.1 \\
\hline & Overweight & 331 & 50.3 \\
\hline & Fat & 131 & 19.6 \\
\hline \multirow{2}{*}{ Presence of symptoms } & No & 276 & 41.3 \\
\hline & Yes & 392 & 58.7 \\
\hline \multirow[t]{2}{*}{ Presence of parasites } & No & 114 & 33.0 \\
\hline & Yes & 232 & 67.0 \\
\hline \multirow[t]{2}{*}{ Cysticercosis serology } & Negative & 546 & 86.8 \\
\hline & Positive & 83 & 13.2 \\
\hline
\end{tabular}


3.1.3. Determinant factors for positive cysticercosis serology

- Factors associated with the presence of seropositive pigs in a farm

The univariate analyzes demonstrated a link between the presence of pigs seropositive for cysticercosis in the farm and the presence of latrines $(p=0.034)$. However, no statistically significant link was demonstrated with the type of breeding $(p=0.064)$, the breeding system practiced $(p=0.055)$, the notion of washing the pigsty $(p=0.123)$, the distance between the places of defecation and the pigsty $(\mathrm{p}=0.061)$ (table 2$)$.

In multivariate analysis, the presence of seropositive pigs in a farm was associated with presence of wells [OR=2.5 (1-6.31), p 0.049], the notion of veterinary care [2.99 (1.22-7.31), $\mathrm{p}$ 0.016], and the number of pigs sampled by farm [OR=1.23 (1.09-1.42) $\mathrm{p} 0.001]$.

- $\quad$ Factors associated with positive serology for a pig

In univariate analysis, positive serology $(C y s t i+)$ in pig was associated with the mixed breed $(p=0.020)$, an older age $(p=0.042)$, a high weight $(p=0.025)$, its general condition $(p=0.010)$, the absence of symptom $(p=0.008)$ and the place (district) where is the farm $(\mathrm{p}=0.000) .($ Table 4$)$

Table 4. Factors associated with positive serology in pigs collected in univariate analyzes

\begin{tabular}{|c|c|c|c|c|}
\hline Parameters & Items & Cysti - & Cysti+ & $\mathbf{p}$ \\
\hline \multirow{3}{*}{ Race of animal } & Local & $292(53.5)$ & $35(42.2)$ & \multirow{3}{*}{$0.020^{1,2}$} \\
\hline & Metis & $237(43.4)$ & $48(57.8)$ & \\
\hline & improved & $17(03.1)$ & $00(00.0)$ & \\
\hline \multirow[t]{3}{*}{ Animal age group } & $<6$ months & $156(28.6)$ & $14(16.9)$ & \multirow[t]{3}{*}{$0.042^{2}$} \\
\hline & Between 6 and 12 months & $192(35.2)$ & $29(34.9)$ & \\
\hline & $>12$ months & 198(36.3) & $40(48.2)$ & \\
\hline \multirow[t]{2}{*}{ Sex } & Male & $158(28.9)$ & 19(22.9) & \multirow[t]{2}{*}{0.254} \\
\hline & Femelle & $388(71.1)$ & $64(77.1)$ & \\
\hline \multirow{4}{*}{ Animal weight } & $<10 \mathrm{Kg}$ & $175(32.1)$ & $15(18.1)$ & \multirow[t]{4}{*}{$0.025^{2}$} \\
\hline & Between 10 et $30 \mathrm{Kg}$ & $179(32.8)$ & $26(31.3)$ & \\
\hline & Between 30 and $70 \mathrm{Kg}$ & $142(26.0)$ & $31(37.4)$ & \\
\hline & $>70 \mathrm{Kg}$ & $50(09.2)$ & $11(13.2)$ & \\
\hline \multirow{4}{*}{ Animal type } & Pig Breeder & $327(59.9)$ & $62(74.7)$ & \multirow[t]{4}{*}{$0.051^{2}$} \\
\hline & Piglet & $176(32.2)$ & 19(22.9) & \\
\hline & Pig butcher & $34(06.2)$ & $02(02.4)$ & \\
\hline & reformed pig & 09(01.7) & $00(00.0)$ & \\
\hline \multirow{3}{*}{ General condition of the animal } & Lean & $174(31.9)$ & $13(15.7)$ & \multirow[t]{3}{*}{$0.010^{2}$} \\
\hline & Overweight & $262(48.0)$ & $51(61.4)$ & \\
\hline & Fat & $110(20.1)$ & 19(22.9) & \\
\hline \multirow{2}{*}{ Presence of symptoms } & No & $206(37.4)$ & $44(53.0)$ & \multirow[t]{2}{*}{$0.008^{2}$} \\
\hline & Yes & $340(62.3)$ & $39(47.0)$ & \\
\hline \multirow{3}{*}{ Site of the farm } & Aboisso & $152(86.9)$ & $23(13.1)$ & \multirow[t]{3}{*}{$0.000^{2}$} \\
\hline & Agboville & $245(92.1)$ & $21(07.9)$ & \\
\hline & Dabou & $149(79.3)$ & $39(20.7)$ & \\
\hline
\end{tabular}

${ }^{1}$ Fisher's exact test $;{ }^{2}$ Variables selected for the multivariate logistic regression model Multivariate 
In multivariate analysis, compared with lean pigs, overweighted pigs and fat ones had more often a positive serology $[\mathrm{OR}=2.6(1.4-4.9)$ p $0.003 ; 2.3(1.1-4.9)$ p 0027 , respectively].

\section{Discussion}

Serological surveys conducted in rural areas commercially connected to Abidjan, had the objective to estimate circulation of Taenia solium in herds. An estimated prevalence of $13.2 \%$ was found over the three districts. However, this prevalence greatly varied from a village to another and risk factor analysis provides interesting data, usable for public health messages. Among the 116 farms visited, $84.5 \%$ harbored at least one infected pig which highlight a large spread of the disease over these districts. The general practice of breeding was the traditional permanent straying as in most of African villages. In the same way as other West African rural areas the local breed was the most exploited compared to the mestizo and exotic breeds [11,12]. In Central and West Africa, authors reported that the traditional system was mainly practiced in peasant areas and in forests [13]. In Burkina Faso, traditional village pig breeding represented up to $90 \%$ of the national herd [14].

This study highlighted factors associated with positive serology for cysticercosis, linked to practices of breeders. Seropositive pigs were more often detected in the farms where breeders declared providing them with well water, and especially when breeding are located less than 100 meters from household landfills usually used for open defecation. Well water can thus be contaminated by human excreta. This contamination could also arise from runoff, sewage or sewage water that would carry the eggs of parasites present in the environment into these wells. These herds fed by well water were mostly in enclosures and therefore benefited from the same water sources. These conditions favor the rapid transmission of parasites between animals and therefore the rapid spread of disease [13]. This study also showed that mixed breed pigs were more often seropositive compared to other breeds. Compared to the local race, this mixed race would have a lower immunity. However, the same study conducted in slaughterhouses from Madagascar showed the opposite results [15] suggesting that the different breeding conditions and especially water supply sustained contamination. In the same line, in this study, older pigs (and in the same way fatter ones) had a higher seroprevalence than younger ones in univariate analysis but not in multivariate model. This is in accordance with authors in Africa $[16,17]$ but not in South America $[18,19]$. The age of slaughtering should sustain this discrepancy: the older, the higher probability of contamination. Overall, these results mean that, ultimately, breeding condition is the main factor of contamination and especially the water supply.

Paradoxically, most of seropositive pigs are reported in farms where breeders reported giving them veterinary care and especially declared using antiparasitics. This can underline that they know that of problem occurs in their herd. However, a lack of knowledge of administration protocols induces a misuse of these molecules. However, this can be a good point of entry to improve education of these breeders. In the opposite way, other breeders in rural areas did not even conceive that a pig could be sick. Indeed, some authors have shown that the majority of breeders in rural areas did not care for their animals. It would seem that veterinary cares were only not reserved for farmers who practiced so-called improved breeding [20]. The use of veterinary products or the use of a veterinarian seems to be seen as a practice in urban areas [20].

\section{Conclusions}

Controlling cysticercosis in pigs is the first way to prevent the spread of infection. Older and fatty animals, consuming well water and breed closed to the household were the most infected animals. It is thus important to educate the population on breeding practices. Pigs should be confined in pens or in a site where they do not have access to 
human feces, and should receive adequate foods, water and veterinary care. The population should be sensitized to hygienic practices such as the construction of latrines away from enclosures of breeding animals in order to prevent the spread of parasite eggs into the environment.

Author Contributions: Conceptualization, SKM, MB, RJ; methodology, SKM, MB, RJ, OMB; validation, SMK, RJ; formal analysis KEK, KBD, CM, JM.; investigation, KEK, OMB; resources, JB, $\mathrm{MN}$; data curation, SMK, KEK; writing - original draft preparation, KEK, SMK, RJ; writing - review and editing, KEN, AOT; visualization, X.X.; supervision, JD, KEN, OAT, RJ; project administration, SMK, RJ; funding acquisition, RJ. All authors have read and agreed to the published version of the manuscript.

Funding: "This research was funded by a grant from the PASRES program (Swiss Cooperation) and PasteurInnov program (Institute Pasteur, Paris) and was also funded by Institut Pasteur de Côte d'Ivoire.

Data Availability Statement: Data are covered by administrative approval. They can be obtained from the authors through reasonable requests

Acknowledgments: We would like to thank all the producers of pigs, the field investigators (ANADER and Veterinary Services) of Dabou, Aboisso and Agboville for allowing us to lead the investigation. We also thank the entire EpiCysti team of IPCI for its technical support.

Conflicts of Interest: The authors declare no conflict of interest. The funders had no role in the design of the study; in the collection, analyses, or interpretation of data; in the writing of the manuscript, or in the decision to publish the results.

\section{References}

1. Preux, P. Cysticercosis and neurocysticerosis in Africa: current status. Neurol Infect Epidemiol 1996, 1, 63-68.

2. Geerts, S. Cysticercosis in Africa. Parasitology today (Personal ed.) 1995, 11, 389; author reply 389-390.

3. Carpio, A.; Escobar, A.; Hauser, W.A. Cysticercosis and epilepsy: a critical review. Epilepsia 1998, 39, 1025-1040.

4. Mishra, G.; N'depo, A. Les cysticerques des animaux abattus à l'abattoir de Port-Bouet (Abidjan). Revue d'élevage et de médecine vétérinaire des pays tropicaux 1978, 31, 431-436.

5. Danho, T. Cysticercose musculaire et trichinellose du porc: cas particulier de la Côte d'Ivoire. 1991.

6. Offianan, A.; Koffi, E.; Boka, O.; Cisse, D.; Meite, A.; Angora, K.; Soumahoro, M.; Assi, B.; Djaman, J.; Jambou, R. A systematic review of taeniasis/cysticercosis and perspectives in Cote d'Ivoire.

7. N’Guessan, K.; Tra, B.; Koné, M. Étude ethnopharmacologique des plantes antipaludiques utilisées en médecine traditionnelle chez les Abbey et Krobou d'Agboville (Côte-d'Ivoire). Ethnopharmacologia 2009, 44, 42-50.

8. Tsang, V.C.; Brand, J.A.; Boyer, A.E. An enzyme-linked immunoelectrotransfer blot assay and glycoprotein antigens for diagnosing human cysticercosis (Taenia solium). Journal of Infectious Diseases 1989, 159, 50-59.

9. Michelet, L. Le complexe taeniase/cysticercose: la phylogénie et l'évolution de Taenia solium et la biologie moléculaire appliquée au diagnostic. Université de Limoges, 2010.

10. Muro, C.; Gomez-Puerta, L.A.; Flecker, R.H.; Gamboa, R.; Barreto, P.V.; Dorny, P.; Tsang, V.C.; Gilman, R.H.; Gonzalez, A.E.; Garcia, H.H. Porcine cysticercosis: possible cross-reactivity of Taenia hydatigena to GP50 antigen in the enzymelinked immunoelectrotransfer blot assay. The American journal of tropical medicine and hygiene 2017, 97, 1830-1832.

11. Missohou, A.; Niang, M.; Foucher, H.; Dieye, P.N. Les systèmes d'élevage porcin en Basse Casamance (Sénégal). Cahiers Agricultures 2001, 10, 405-408.

12. Secka, A.; Marcotty, T.; De Deken, R.; Van Marck, E.; Geerts, S. Porcine cysticercosis and risk factors in The Gambia and Senegal. Journal of parasitology research 2010, 2010.

13. Agbokounou, A.M.; Ahounou, G.S.; Youssao, A.; Mensah, G.; Koutinhouin, B.; Hornick, J.-L. Caractéristiques de l'élevage du porc local d'Afrique. Journal of Animal \&Plant Sciences 2016, 30, 4701-4713. 
14. FAO. Secteur porcin Burkina Faso. Revues nationales de l'élevage de la production et de la santé animales de la FAO. N ${ }^{\circ} 12012$.

15. Clément, R.A.L. EVOLUTION SPATIALE ET SAISONNIERE DE LA CYSTICERCOSE PORCINE A MADAGASCAR PAR UN SUIVI D'ABATTOIR. EVOLUTION 2016.

16. Nguekam, J. La Cysticercose Porcine dans les Departements de la Mifi et des Bamboutos. Master of Science Thesis, Institut de la Médicine Tropicale, Anvers-Belgique. $42 p 1998$.

17. Pondja, A.; Neves, L.; Mlangwa, J.; Afonso, S.; Fafetine, J.; Willingham III, A.L.; Thamsborg, S.M.; Johansen, M.V. Prevalence and risk factors of porcine cysticercosis in Angonia District, Mozambique. PLoS Negl Trop Dis 2010, 4, e594.

18. Mopate-Logtene, L.; Koussou, M.; Nguertoum, E.; Ngo, T.; Lakouetene, T.; Awa, D.; MalMal, H. Caractéristiques et performances des élevages porcins urbains et périurbains des savanes d'Afrique Centrale: cas des villes de Garoua, Pala et Bangui. Savanes africaines en développement: innover pour durer, Garoua: Cameroun 2009, 9.

19. Sarti, E.; Schantz, P.M.; Plancarte, A.; Wilson, M.; Gutierrez, I.O.; Lopez, A.S.; Roberts, J.; Flisser, A. Prevalence and risk factors for Taenia solium taeniasis and cysticercosis in humans and pigs in a village in Morelos, Mexico. The American journal of tropical medicine and hygiene 1992, 46, 677-685.

20. Youssao, A.I.; Koutinhouin, G.; Kpodekon, T.; Bonou, A.; Adjakpa, A.; Dotcho, C.; Atodjinou, F. Production porcine et ressources génétiques locales en zone périurbaine de Cotonou et d'Abomey-Calavi au Bénin. Revue d'élevage et de médecine vétérinaire des pays tropicaux 2008, 61, 235-243. 